\title{
Bioaccumulation and health risk assessment of heavy metals in Musa paradisiaca, Zea mays, Cucumeropsis manii and Manihot esculenta cultivated in Onne, Rivers State, Nigeria
}

\author{
Franklyn 0. Ohiagu', Kelechi C. Lele', Paul C. Chikezie ${ }^{1}{ }^{1}$, Andrew W. Verla ${ }^{2}$, Christian E. Enyoh ${ }^{2}$ (]) \\ 'Department of Biochemistry, Imo State University, Owerri, Nigeria; ${ }^{2}$ Department of Chemistry, Imo State University, Owerri, Nigeria
}

This study was carried out to investigate heavy metals concentrations: lead (Pb), cobalt (Co), cadmium (Cd), zinc ( $\mathrm{Zn})$, nickel (Ni), copper (Cu) and manganese (Mn) in Musa paradisiaca (plantain), Zea mays (maize), Cucumeropsis manii (melon), Manihot esculenta (cassava) and soil samples from dumpsites in Onne, Eleme Local Government Area, Rivers State, Nigeria. The plant leaf and soil samples were measured for heavy metals concentrations using atomic absorption spectrophotometer. The health risk index (HRI) of the heavy metals following the consumption of these plant materials by the populace was estimated using standard protocols. The heavy metals concentrations in the leaf samples ranged from $0.012-14.712 \mathrm{mg} / \mathrm{kg}$, whereas those of the soil samples were within the range of $2.543-16.459 \mathrm{mg} / \mathrm{kg}$. Cd concentrations in the soil and leaf samples were above the maximum permissible level according to the World Health Organization (WHO). The bioaccumulation of the heavy metals followed the trend: $(M$. paradisiaca) $\mathrm{Zn}>\mathrm{Pb}>\mathrm{Co}>\mathrm{Mn}>\mathrm{Cu}>\mathrm{Cd}>\mathrm{Ni}$; (Z. mays) $\mathrm{Mn}>\mathrm{Pb}>\mathrm{Co}>\mathrm{Zn}>\mathrm{Cu}>\mathrm{Cd}>\mathrm{Ni}$; (C. mannii) $\mathrm{Mn}>\mathrm{Co}>\mathrm{Pb}>\mathrm{Cu}>\mathrm{Zn}$ $>\mathrm{Cd}>\mathrm{Ni}$; (M. esculenta) $\mathrm{Zn}>\mathrm{Pb}>\mathrm{Mn}>\mathrm{Cu}>\mathrm{Co}>\mathrm{Ni}>\mathrm{Cd}$. The highest bioaccumulation of the heavy metals occurred in $\mathrm{M}$. esculenta. The estimated $\mathrm{HRI}$ of $\mathrm{Pb}$ in $\mathrm{M}$. esculenta was greater than 1 . $\mathrm{HRI}>1$ was indicative that the consumer population is not safe. Cassava-based meals from the dumpsites contained $\mathrm{Pb}$ at toxic level, whereas $\mathrm{Co}, \mathrm{Cd}, \mathrm{Zn}, \mathrm{Ni}, \mathrm{Cu}$, and $\mathrm{Mn}$ concentrations in plantain-, maize- and melon-based meals were relatively within safe limits.

Keywords: bioaccumulation, Cucumeropsis manii, heavy metals, Manihot esculenta, Musa paradisiaca, Zea mays

\section{Introduction}

Musa paradisiaca L. (plantain), which belongs to the Musaceae family, is a perennial herbaceous plant that is widely distributed in the tropical and subtropical regions of the world. $M$. paradisiaca grows up to a height of $9 \mathrm{~m}$ above the ground. The pseudostem is characterized by concentrically formed leaves and roughly ellipsoidal fleshy fruits [1,2]. Zea mays L. (maize) is a well-known cereal that originated from Mexico, Central America and belongs to the Poaceae family. Z. mays is an annual tall herb that possesses widespread fibrous roots [3]. Cucumeropsis mannii N. (melon), a member of the Cucurbitaceae family, is an indigenous crop of West Africa and is popularly called "egusi" in this region. C. mannii is a tendril creeping an-

Received: Mar 31, 2020 Accepted: June 13, 2020

Corresponding author: Paul C. Chikezie

Department of Biochemistry, Imo State University, PMB 2000, Owerri, Nigeria

E-mail: p_chikezie@yahoo.com

This article is available from: http://e-eht.org/ nual crop characterized by a shallow fibrous root system. The seeds of C. mannii are rich sources of lipids [4]. Manihot esculenta C. (cassava) is an annual woody shrub with tuberous roots. The plant is a native of South America and belongs to the Euphorbiaceae family. M. esculenta is widely cultivated both as a food crop and cash crop in Africa, Asia and the Caribbean $[5,6]$. The vast nutraceutical potentials of $M$. paradisiaca, Z. mays, C. manii and M. esculenta have been reviewed elsewhere [1-3,5,7].

Heavy metals remain one of the major contaminants of food crops. At trace levels, certain heavy metals contribute to body development, but intake of higher than daily dietary requirement could be detrimental to human health [8]. Heavy metals are non-biodegradable and can accumulate in the soil at toxic levels [9]. These metals are introduced into the environment via different anthropogenic activities such as mining, diffuse sources such as piping, combustion of byproducts and other human activities [10].

Onne, Eleme Local Government Area (L.G.A.), Rivers State, 
Nigeria is one of the prominent Nigerian seaports used for oil and gas explorations. Environmental pollution in Onne community has been a problem of great concern over the years. Large amount of black dust, soot, powder, ash or carbon particles settle on just anything including the inhabitants. The sustained black soot deposit in the atmosphere is due to the uncontrolled incineration of crude oil [11]. Oil mining, refining and processing have been the major source of energy globally. These activities are accompanied with the release of large quantities of heavy metals such as lead (Pb), cobalt (Co), cadmium $(\mathrm{Cd})$, zinc $(\mathrm{Zn})$, nickel $(\mathrm{Ni})$, copper $(\mathrm{Cu})$, manganese (Mn), etc. [12]. According to the study carried out by Asia et al., [13] in the Niger Delta, petroleum exploration and production operations caused the release of certain heavy metals such as $\mathrm{Pb}, \mathrm{Cu}, \mathrm{Ni}$, and $\mathrm{Co}$ into the soil and groundwater. Oil spillages, leaking underground storage tanks and pipes have been identified as the major sources of contamination [10] in oil producing areas such as Onne. As a result, higher levels of certain heavy metals was reported in cassava flakes (garri) from Onne [14] compared with those produced in non-oil mining area of Yenagoa metropolis [15].

Petroleum exploration and production operations involve the use of various chemicals to ensure the protection of oil wells and the separation of oil from water. Such chemicals can pollute the soil in areas where such operations are not properly regulated in accordance with the guidelines stated by regulatory agencies such as the Department of Petroleum Resources (DPR) and Federal Ministry of Environment of Nigeria [13]. Heavy metals pollute the soil by altering the soil $\mathrm{pH}$, thus making the soil unsafe for agricultural activities [12]. Plants cultivated on such contaminated soils absorb these heavy metals and when consumed, predisposes the consumer to various health hazards.

This study was carried out to investigate heavy metals concentrations: $\mathrm{Pb}, \mathrm{Co}, \mathrm{Cd}, \mathrm{Zn}, \mathrm{Ni}, \mathrm{Cu}$, and $\mathrm{Mn}$ in $M$. paradisiaca, Z. mays, C. manii, M. esculenta and soil samples from dumpsites in Onne. Furthermore, the present study ascertained the bioconcentration factor $(\mathrm{BF})$ and related toxicological indices in order to establish the levels of human exposure to heavy metals within the locations of the dumpsites in relation to health risk indicators associated with the consumption of these food crops.

\section{Materials and Methods}

Description of the study area

The study was carried out in Onne Nigeria. $\left(4^{\circ} 43^{\prime} 0^{\prime \prime} \mathrm{N}\right.$ $\left.7^{\circ} 9^{\prime} 0^{\prime \prime} \mathrm{E}\right)$. The major plants cultivated in the dumpsite areas include cassava, maize, oil palm fruit, yam, fluted pumpkin, melon, and bitter leaf. These dumpsites were chosen for this study because of the oil mining activities in the areas, which are associated with the release of large amount of pollutants into the environment.

\section{Collection and preparation of samples}

Fifteen fresh leaf samples of M. paradisiaca, Z. mays, C. manii, and M. esculenta were harvested using a knife from subareas of the four dumpsites. The coordinates (latitude and longitude) of the collection points of the leaf samples were referenced using GPS map ${ }^{\circledR} 76$ (Garmin Ltd.): (M. paradisiaca) $4^{\circ} 44^{\prime} 44.876^{\prime \prime} \mathrm{N} 7^{\circ} 9^{\prime} 15.672^{\prime \prime} \mathrm{E}$; (Z. mays) $4^{\circ} 44^{\prime} 43.453^{\prime \prime} \mathrm{N}$ $7^{\circ} 9^{\prime} 14.392^{\prime \prime} \mathrm{E}$; (C. manii) 44ㄴ $42.211^{\prime \prime} \mathrm{N} 7^{\circ} 9^{\prime} 13.455^{\prime \prime} \mathrm{E} ;(M$. esculenta) $4^{\circ} 44^{\prime} 44.997^{\prime \prime} \mathrm{N} 7^{\circ} 9^{\prime} 14.653^{\prime \prime} \mathrm{E}$ (Figure 1). The leaf samples were washed under flowing current of deionized water to remove soil and dust particles and dried in an oven at $50^{\circ} \mathrm{C}$ until they became crispy. The separate dried leaf samples were crushed into fine powder using ceramic mortar and pestle, and stored in well labeled air tight containers pending analysis [16].

Soil samples were collected from sub-areas of the four dumpsites using a soil auger at $10 \mathrm{~cm}$ depth (top soil) [17]. Eighteen soil samples from each sub-area were pooled and sieved to remove unwanted soil particles and debris. The prepared soil samples were dried in an oven at $50^{\circ} \mathrm{C}$ to constant weight and represented the composite soil samples from the designated dumpsites. The separate composite dried soil samples were stored in corresponding air tight containers.

\section{Digestion and analyses of leaf and soil samples}

One gram ( $1.0 \mathrm{~g})$ of the powdered leaf and soil samples were weighed into separate corresponding test tubes and digested in $24 \mathrm{~mL}$ of aqua regia $\left(\mathrm{HCl}: \mathrm{HNO}_{3}=3: 1 v / v\right)$ for three days as previously described $[16,18]$. The concentrations of $\mathrm{Pb}, \mathrm{Co}$, $\mathrm{Cd}, \mathrm{Zn}, \mathrm{Ni}, \mathrm{Cu}$, and $\mathrm{Mn}$ in the leaf and soil samples were measured triplicate using atomic absorption spectrophotometer (Buck Model 210) according to the methods previously reported [19].

\section{Ratio of plant leaf to soil bioaccumulation of heavy metals}

From the results of $\mathrm{Pb}, \mathrm{Co}, \mathrm{Cd}, \mathrm{Zn}, \mathrm{Ni}, \mathrm{Cu}$ and $\mathrm{Mn}$ concentrations in M. paradisiaca, Z. mays, C. manii, and M. esculenta leaf and soil samples, the ratio of plant leaf to soil bioaccumulation of heavy metal (RBHM) or BF was calculated [20].

$$
\mathrm{RBHM}=\frac{\text { HMCPS }}{\text { HMCSS }}
$$

where HMCPS is heavy metal concentration of a leaf sample 


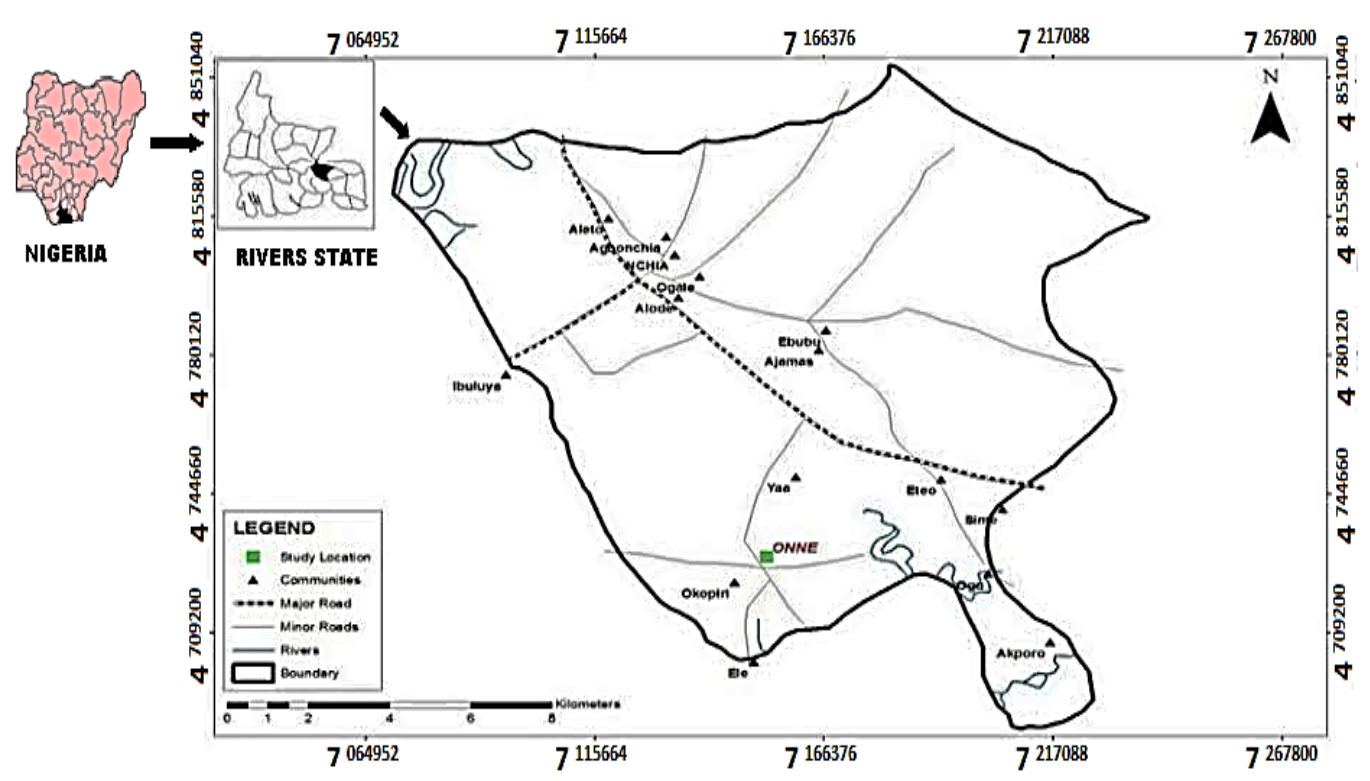

Figure 1. Map of Eleme L.G.A. showing the study location.

and HMCSS is heavy metal concentration of soil sample.

\section{Daily intake of heavy metals}

The daily intake of heavy metals (DIHM, mg/kg person/day) was estimated in relation to the body weights of consumers of M. paradisiaca, Z. mays, C. manii, and M. esculenta. Because DIHM by individuals is directly proportional to average daily consumption of the plant leaf, DIHM was calculated [21]. Thus:

$$
\mathrm{DIHM}=\frac{\mathrm{C}_{\mathrm{HM}} \times \mathrm{D}_{\mathrm{FI}}}{\mathrm{B}_{\mathrm{AW}}}
$$

where $\mathrm{C}_{\mathrm{HM}}$ is heavy metal concentration in plant leaf (mg/ $\mathrm{kg}$ ), $\mathrm{D}_{\mathrm{FI}}$ is daily consumption of $M$. paradisiaca, Z. mays, $C$. manii, and M. esculenta by adults and children based on related studies $[19,21]$, which was put at estimated averages of 0.345 and $0.232 \mathrm{~kg}$-person/day, respectively, and BAW is average body weights of the consumers based on field estimations using a mobile weighing scale (Hana instrument; China), which was put at $55.9 \mathrm{~kg}$ and $32.7 \mathrm{~kg}$ for adults and children, respectively [21].

\section{Health risk index}

The health risk index (HRI) was estimated as described in previous literature [22].

$$
\mathrm{HRI}=\frac{\mathrm{DIHM}}{\mathrm{ORD}}
$$

where ORD: Oral reference dose ( $\mathrm{mg} / \mathrm{kg}$ person/day). The ORD is an estimated exposure of metal to the human body per day associated with no potential hazardous effect during lifetime. The ORD (mg/kg person/day) for $\mathrm{Pb}, \mathrm{Co}, \mathrm{Cd}, \mathrm{Zn}, \mathrm{Cu}$, and Mn used were 0.004, 0.02, 0.001, 0.3, 0.02, 0.04, and 0.033 $\mathrm{mg} / \mathrm{kg}$ person/day, respectively [22,23]. The consumer population is considered safe when HRI is less than 1 [21].

\section{Data anallyses}

The data were expressed in terms of range of values in comparison with standard reference quantity according to the World Health Organization (WHO) and Food and Agricultural Organization (FAO). The heavy metal concentrations were expressed as mean \pm standard deviation.

\section{Results and discussion}

\section{Heavy metal concentrations in the leaf samples}

The heavy metals concentrations in M. paradisiaca, Z. mays, C. manii, and M. esculenta leaf samples from the dumpsites in Onne are presented in Table 1. The heavy metal concentrations in the leaf samples were in the following order: $\mathrm{Zn}>\mathrm{Co}>$ $\mathrm{Mn}>\mathrm{Pb}>\mathrm{Cu}>\mathrm{Cd}>\mathrm{Ni}$ for $M$. paradisiaca; $\mathrm{Mn}>\mathrm{Zn}>\mathrm{Co}>\mathrm{Pb}$ $>\mathrm{Cu}>\mathrm{Cd}>\mathrm{Ni}$ for Z. mays; $\mathrm{Mn}>\mathrm{Co}>\mathrm{Cu}>\mathrm{Zn}>\mathrm{Pb}>\mathrm{Cd}>\mathrm{Ni}$ for $C$. mannii; $\mathrm{Zn}>\mathrm{Mn}>\mathrm{Cu}>\mathrm{Pb}>\mathrm{Co}>\mathrm{Ni}>\mathrm{Cd}$ for $M$. esculenta. The ranges of the heavy metals concentrations in the leaf samples were: $\mathrm{Pb}$ : $0.188 \pm 0.05-0.608 \pm 0.01 \mathrm{mg} / \mathrm{kg}$; Co: $0.426 \pm 0.02-1.521 \pm 0.02 \mathrm{mg} / \mathrm{kg} ; \mathrm{Cd}: 0.082 \pm 0.02-0.101 \pm 0.00$ $\mathrm{mg} / \mathrm{kg}$; Zn: $0.274 \pm 0.04-14.712 \pm 0.20 \mathrm{mg} / \mathrm{kg} ; \mathrm{Ni}: 0.012 \pm 0.05-$ $0.504 \pm 0.11 \mathrm{mg} / \mathrm{kg}$; Cu: $0.235 \pm 0.11-1.967 \pm 0.04 \mathrm{mg} / \mathrm{kg}$; Mn: $0.560 \pm 0.10-3.056 \pm 0.06 \mathrm{mg} / \mathrm{kg}$.

All the heavy metal concentrations in the leaf samples were below the maximum permissible level of the WHO, whereas the concentrations of Co (C. mannii), Zn (M. paradisiaca, Z. 
Table 1. Maximum permissible limits (MPL) of heavy metals in soils and plants according to food and agriculture organization and world health organization (WHO/FA0) [24-26] and heavy metal concentrations (HMC) in leaf and soil samples from dumpsites in Onne

\begin{tabular}{|c|c|c|c|c|c|c|c|}
\hline \multirow{2}{*}{ Heavy metals } & \multicolumn{2}{|c|}{ MPL (mg/kg) } & \multicolumn{4}{|c|}{ Leaf Samples HMC (mg/kg) } & \multirow{2}{*}{$\begin{array}{c}\text { Soil Samples HMC } \\
(\mathrm{mg} / \mathrm{kg})\end{array}$} \\
\hline & Soil & Plant & M. paradisiaca & Z. mays & C. mannii & M. esculenta & \\
\hline Lead (Pb) & 85 & 2 & $0.447 \pm 0.03$ & $0.267 \pm 0.00$ & $0.188 \pm 0.05$ & $0.608 \pm 0.01$ & $2.543 \pm 0.99$ \\
\hline Cobalt (Co) & $N D^{b}$ & 1.5 & $0.875 \pm 0.00$ & $0.426 \pm 0.02$ & $1.521 \pm 0.02$ & $0.515 \pm 0.03$ & $8.173 \pm 1.96$ \\
\hline Cadmium (Cd) & 0.8 & 0.02 & $0.082 \pm 0.02$ & $0.093 \pm 0.06$ & $0.097 \pm 0.01$ & $0.101 \pm 0.00$ & $7.540 \pm 4.40$ \\
\hline Zinc (Zn) & 50 & 0.6 & $6.657 \pm 0.05$ & $0.787 \pm 0.03$ & $0.274 \pm 0.04$ & $14.712 \pm 0.20$ & $16.459 \pm 2.82$ \\
\hline Nickel (Ni) & 35 & 10 & $0.026 \pm 0.05$ & ND & $0.012 \pm 0.05$ & $0.504 \pm 0.11$ & $12.004 \pm 1.35$ \\
\hline Copper (Cu) & 36 & 10 & $0.439 \pm 0.04$ & $0.235 \pm 0.11$ & $0.375 \pm 0.01$ & $1.967 \pm 0.04$ & $14.791 \pm 1.19$ \\
\hline Manganese (Mn) & $N D^{b}$ & 200 & $0.560 \pm 0.10$ & $1.641 \pm 0.05$ & $2.847 \pm 0.04$ & $3.056 \pm 0.06$ & $13.949 \pm 3.57$ \\
\hline
\end{tabular}

ND: not detected.

mays, M. esculenta), and Cd (M. paradisiaca, Z. mays, C. mannii, M. esculenta) were higher than the WHO permissible limits (Table 1). The Mn concentrations in the leaf samples were very low when compared with the WHO permissible level for $\mathrm{Mn}(200 \mathrm{mg} / \mathrm{kg})$. The low Mn concentration was probably due to leaching of the metal to deeper strata of the soil.

Co at high doses is cytotoxic causing apoptosis, necrosis and genotoxicity [27]. Cd is a highly toxic heavy metal that even at low concentration does not have any useful biological role in living organisms $[18,28]$. Cd poisoning causes lung cancer, anaemia, kidney failure and bone disorder [29]. $\mathrm{Zn}$ is known to play a major role in body development and function, but excessive exposure to $\mathrm{Zn}$ can provoke respiratory disorder, epigastric pain, diarrhea, elevated risk to prostate cancer, focal neuronal deficits and nausea [30].

The concentrations of $\mathrm{Cd}, \mathrm{Zn}, \mathrm{Ni}, \mathrm{Cu}$, and $\mathrm{Mn}$ in leaf samples of $M$. esculenta from the study area were lower than that reported in leaf and tuber samples from Galena Mining Area in Ishiagu, Ebonyi State, Nigeria [31]. The concentrations of Ni, $\mathrm{Zn}, \mathrm{Cu}$ and $\mathrm{Pb}$ in leaf samples of $M$. paradisiaca from farmlands in Kaani and Kpean in Khana L.G.A. of Rivers State, Nigeria, [32] were higher than those reported in the present study. Additionally, reports by Ajayi and Salami [33] showed relatively higher concentrations of $\mathrm{Cu}$ and $\mathrm{Zn}$ but lower concentration of $\mathrm{Mn}$ in C. mannii from a farm at Bode-Saadu in Ilorin, Kwara State, Nigeria, than those reported in the present study. Conversely, the present study reported higher concentrations of $\mathrm{Co}, \mathrm{Cd}, \mathrm{Zn}$, and $\mathrm{Cu}$ in $\mathrm{Z}$. mays than those reported by Akenga et al. [34]

\section{Heavy metal concentrations in the soill samples}

Table 1 showed the concentrations of $\mathrm{Pb}, \mathrm{Co}, \mathrm{Cd}, \mathrm{Zn}, \mathrm{Ni}, \mathrm{Cu}$, and $\mathrm{Mn}$ in the soil samples collected from four designated points of the dumpsites in Onne. The mean concentrations of the heavy metals followed the order: $\mathrm{Zn}>\mathrm{Cu}>\mathrm{Mn}>\mathrm{Ni}>\mathrm{Co}>$ $\mathrm{Cd}>\mathrm{Pb}$.
All heavy metals concentrations in the soil samples were within the permissible level of WHO [26], with the exception to $\mathrm{Cd}$, which gave a concentration of $7.540 \mathrm{mg} / \mathrm{kg}$ as against the WHO maximum permissible level of $0.8 \mathrm{mg} / \mathrm{kg}$. The concentration of $\mathrm{Cd}$ in the soil samples from this area was higher than that reported for Shao North Central Nigeria, Nigeria by Ogundele et al.[24] which was $0.033 \mathrm{mg} / \mathrm{kg}$. Also, Opaluwa et al. [35] noted that $\mathrm{Cd}$ concentration in soil samples from dumpsites in Lafia Metropolis, Nasarawa State, Nigeria was $0.48 \mathrm{mg} / \mathrm{kg}$, which was lower than that reported in the present study area. These are indications that the soil samples from Onne were highly polluted with $\mathrm{Cd}$. The high concentration of $\mathrm{Cd}$ in the soil samples from the area of study is due to the oil mining activities, industrial processing activities, use of fertilizers and pesticides in agricultural activities, sewage sludge and uncontrolled waste disposal in Onne.

The concentration of $\mathrm{Zn}$ from soil samples from the present area of study was higher than the $\mathrm{Zn}$ concentration reported by Ibe et al. [16] in abandoned municipal waste dumpsites in Owerri, Imo State, Nigeria, which gave a concentration of 1.07 $\mathrm{mg} / \mathrm{kg}$. Fosu-Mensah et al. [36] also reported a lower Zn concentration $(2.05 \mathrm{mg} / \mathrm{kg})$ from reclaimed waste dumpsites at Korle Lagoon area in Accra, Ghana. The mean Ni concentration $(34.78 \mathrm{mg} / \mathrm{kg}$ ) from a waste disposal site in Ibadan, Nigeria as described by Auta and Morenikeji [37] and that reported by Ofudje et al. [38] from Lagos, Nigeria gave Ni concentration of $64.17 \mathrm{mg} / \mathrm{kg}$. The concentration of $\mathrm{Ni}$ in soil samples from the present study area was lower than those described elsewhere $[37,38]$. A lower concentration of $\mathrm{Cu}$ was noted in soil samples from the present study sites compared with the concentration of $\mathrm{Cu}(18.00 \mathrm{mg} / \mathrm{kg})$ in Corlu-Cerkezkoy highway, Thrace region, Turkey [39]. Additionally, Ibe et al. [16] reported higher concentration of $\mathrm{Cu}(15.7 \mathrm{mg} / \mathrm{kg})$ in soil samples from Owerri, Imo State, Nigeria. Soil samples from Suburban roadside farmland in Nepal gave $\mathrm{Pb}$ concentration of $31.81 \mathrm{mg} / \mathrm{kg}$ [40], which was higher than that of the present study. Accord- 
ing to Lago-Vila et al., [20] relatively high concentration of Co $(110 \mathrm{mg} / \mathrm{kg}$ ) was reported in soil samples from Moeche, Coruna, Spain.

\section{Ratio of plant leaf to soil bioaccumulation of heavy metals} Among the analyzed four leaf samples, the M. esculenta exhibited highest bioaccumulation of $\mathrm{Pb}, \mathrm{Cd}, \mathrm{Zn}, \mathrm{Ni}, \mathrm{Cu}$, and $\mathrm{Mn}$, whereas $C$. mannii gave the highest concentration of Co. The ratio of plant leaf to soil bioaccumulation of $\mathrm{Cd}$ and $\mathrm{Mn}$ was lowest in $M$. paradisiaca. Likewise, the ratio of plant leaf to soil bioaccumulation of $\mathrm{Co}$ and $\mathrm{Cu}$ were lowest in Z. mays, whereas $\mathrm{Pb}, \mathrm{Zn}$, and $\mathrm{Ni}$ were lowest in $C$. mannii. The pattern of increase in bioaccumulation of heavy metals in the leaf samples were as follows: $\mathrm{Zn}>\mathrm{Pb}>\mathrm{Co}>\mathrm{Mn}>\mathrm{Cu}>\mathrm{Cd}>\mathrm{Ni}(M$. paradisiaca); $\mathrm{Mn}>\mathrm{Pb}>\mathrm{Co}>\mathrm{Zn}>\mathrm{Cu}>\mathrm{Cd}>\mathrm{Ni}$ (Z. mays); $\mathrm{Mn}$ $>\mathrm{Co}>\mathrm{Pb}>\mathrm{Cu}>\mathrm{Zn}>\mathrm{Cd}>\mathrm{Ni}$ (C. mannii); $\mathrm{Zn}>\mathrm{Pb}>\mathrm{Mn}>\mathrm{Cu}$ $>\mathrm{Co}>\mathrm{Ni}>\mathrm{Cd}$ (M. esculenta) (Table 2).

The transfer factor of heavy metals from soil to plants is the ratio of the concentration of heavy metals in a plant to the concentration of heavy metal in the soil-RBHM [20]. The transfer factor signifies the extent at which heavy metals in the soil accumulated in the plants. The RBHM was calculated in order to have a good knowledge of the extent of risk and hazard associated with the ingestion of plants from the study area. The soil-to-plant transfer factor is one of the key components of the measure of level of human exposure to metals in the food chain $[16,41,42]$.

According to Okereke et al., [21] the physicochemical properties of soil and plants could influence the transfer or mobility of metals from soil to plant. These physicochemical properties are on the other hand influenced by industrial activities such as oil mining. Thus, the RBHM of the various heavy metals in this study area might have been influenced by oil mining activities and other industrial processes going on in the area. The RBHM of the heavy metals were noted to vary directly with the heavy metal concentration in the leaf samples. Therefore, it implies that the transfer factor of heavy metals from soil to plants was a determinant of the level of heavy metal pollution of the plants cultivated in the area.

The high RBHM of most of the heavy metals for M. esculenta was an indication that the cassava cultivated in Onne were highly polluted by these contaminants and thus can be trans-

Table 2. Ratio of plant leaf to soil bioaccumulation of heavy metals from dumpsites in Onne

\begin{tabular}{lccccccc}
\hline \multirow{2}{*}{ Plant samples } & \multicolumn{5}{c}{ Ratio } \\
\cline { 2 - 7 } & Lead (Pb) & Cobalt (Co) & Cadmium (Cd) & Zinc (Zn) & Nickel (Ni) & Copper (Cu) & Manganese (Mn) \\
\hline Musa paradisiaca & 0.176 & 0.107 & 0.011 & 0.404 & $2.17 \times 10^{-3}$ & 0.030 & 0.040 \\
Zea mays & 0.105 & 0.052 & 0.012 & 0.048 & ND & 0.016 & 0.118 \\
Cucumeropsis mannii & 0.074 & 0.186 & 0.013 & 0.017 & $9.997 \times 10^{-4}$ & 0.025 & 0.204 \\
Manihot esculenta & 0.239 & 0.063 & 0.013 & 0.894 & 0.042 & 0.133 & 0.219 \\
\hline
\end{tabular}

ND: not detected.

Table 3. Daily intake of heavy metals of adults ( $\mathrm{mg} / \mathrm{kg}$ person/day) in Onne

\begin{tabular}{|c|c|c|c|c|c|c|c|}
\hline \multirow{2}{*}{ Leaf samples } & \multicolumn{7}{|c|}{ Daily intake (mg/kg person/day) } \\
\hline & Lead $(\mathrm{Pb})$ & Cobalt (Co) & Cadmium (Cd) & Zinc (Zn) & Nickel (Ni) & Copper (Cu) & Manganese (Mn) \\
\hline Musa paradisiaca & 0.0028 & 0.0054 & 0.0005 & 0.0411 & 0.0002 & 0.0027 & 0.0035 \\
\hline Zea mays & 0.0016 & 0.0026 & 0.0006 & 0.0049 & ND & 0.0015 & 0.0101 \\
\hline Cucumeropsis mannii & 0.0012 & 0.0094 & 0.0006 & 0.0017 & 0.0001 & 0.0023 & 0.0176 \\
\hline Manihot esculenta & 0.0038 & 0.0032 & 0.0006 & 0.0908 & 0.0031 & 0.0121 & 0.0189 \\
\hline Tolerable daily intake [24-26] & 0.0036 & 0.0230 & 0.0010 & 0.4300 & 0.0050 & 0.5000 & 0.0110 \\
\hline
\end{tabular}

ND: not detected.

Table 4. Daily intake of heavy metals of children ( $\mathrm{mg} / \mathrm{kg}$ person/day) in Onne

\begin{tabular}{|c|c|c|c|c|c|c|c|}
\hline \multirow{2}{*}{ Leaf samples } & \multicolumn{7}{|c|}{ Daily intake (mg/kg person/day) } \\
\hline & Lead (Pb) & Cobalt (Co) & Cadmium (Cd) & Zinc $(Z n)$ & Nickel (Ni) & Copper (Cu) & Manganese (Mn) \\
\hline Musa paradisiaca & 0.0032 & 0.0062 & 0.0006 & 0.0472 & 0.0002 & 0.0031 & 0.0040 \\
\hline Zea mays & 0.0019 & 0.0030 & 0.0007 & 0.0056 & ND & 0.0017 & 0.0116 \\
\hline Cucumeropsis mannii & 0.0013 & 0.0108 & 0.0007 & 0.0019 & 0.0001 & 0.0027 & 0.0202 \\
\hline Manihot esculenta & 0.0043 & 0.0037 & 0.0007 & 0.1044 & 0.0036 & 0.0140 & 0.0217 \\
\hline Tolerable daily intake [24-26] & 0.0036 & 0.0230 & 0.0010 & 0.4300 & 0.0050 & 0.5000 & 0.0110 \\
\hline
\end{tabular}

ND: not detected. 
ferred into the human system with the consumption of cassava food products, such as garri, tapioca, fufu, etc. Accordingly, RBHM is very essential in the investigation of human HRI [42, 43].

\section{Daily intake of heavy metals}

The DIHM for adults and children population in the study area are shown in Tables 3 and 4, respectively. The estimated DIHM for both adults and children followed the same trend. The DIHM was in the order: $\mathrm{Zn}>\mathrm{Co}>\mathrm{Mn}>\mathrm{Pb}>\mathrm{Cu}>\mathrm{Cd}>\mathrm{Ni}$ (M. paradisiaca); $\mathrm{Mn}>\mathrm{Zn}>\mathrm{Co}>\mathrm{Pb}>\mathrm{Cu}>\mathrm{Cd}>\mathrm{Ni}$ (Z. mays); $\mathrm{Mn}>\mathrm{Co}>\mathrm{Cu}>\mathrm{Zn}>\mathrm{Pb}>\mathrm{Cd}>\mathrm{Ni}$ (C. mannii); $\mathrm{Zn}>\mathrm{Mn}>\mathrm{Cu}>$ $\mathrm{Pb}>\mathrm{Co}>\mathrm{Ni}>\mathrm{Cd}$ (M. esculenta). Tables 3 and 4 showed that Zn represented the highest DIHM in $M$. paradisiaca for adults and children ( 0.0411 and $0.0472 \mathrm{mg} / \mathrm{kg}$ person/day, respectively) and M. esculenta ( 0.0908 and $0.1044 \mathrm{mg} / \mathrm{kg}$ person/day, respectively). Mn intake for adults and children was the highest in Z. mays ( 0.0101 and $0.0116 \mathrm{mg} / \mathrm{kg}$ person/day, respectively) and C. mannii (0.0176 and $0.0202 \mathrm{mg} / \mathrm{kg}$ person/day, respectively). Additionally, $\mathrm{Ni}$ intake gave the lowest DIHM ( $0.0002 \mathrm{mg} / \mathrm{kg}$ person/day) following the consumption of $M$. paradisiaca and C. mannii (DIHM $=0.0001 \mathrm{mg} / \mathrm{kg}$ person/ day) for adults and children. Cd gave the lowest DIHM following the consumption of M. esculenta and Z. mays.

According to the Joint FAO/WHO Expert Committee on Food Additives (JECFA), the tolerable daily intake of $\mathrm{Pb}, \mathrm{Co}$, $\mathrm{Cd}, \mathrm{Zn}, \mathrm{Ni}, \mathrm{Cu}$ and $\mathrm{Mn}$ was set at 0.0036, 0.0230, 0.0010, 0.4300, $0.0050,0.5000$, and $0.0110 \mathrm{mg} / \mathrm{kg}$ person/day, respectively [44]. The estimated DIHM was all below the provisional tolerable daily intake level specified by JECFA [44], apart from $\mathrm{Pb}$ and $\mathrm{Mn}$. $\mathrm{Pb}$ was high in M. esculenta for both adults and chil- dren; Mn was high in Z. mays for children only and in C. mannii and M. esculenta for both adults and children.

The DIHM of $\mathrm{Pb}, \mathrm{Cd}, \mathrm{Ni}$, and $\mathrm{Cu}$ by the consumption of cassava in the present study were noted to be higher than that reported in Alakahia, Obi-Akpor L.G.A., Rivers State, Nigeria [21]. Osu et al., [22] reported higher DIHM for Pb and Mn following the consumption of cassava from crude oil impacted soil in Ikot Abasi L.G.A., Akwa Ibom State, Nigeria. The estimated DIHM of Cd, Zn, and Ni via Z. mays consumption from District Bannu, Khyber Pakhtunkhwa, Pakistan [45], were higher than that observed in the present study.

\section{Health risk assessment}

Health risk assessment (HRA) defines the basis for establishing health risk posed by the heavy metals by the consumption of M. paradisiaca, Z. mays, C. mannii, and M. esculenta. Accordingly, HRA encapsulates the DIHM and HRI. The calculated DIHM and HRI for both adults and children are presented in Tables 3-6.

Tables 5 and 6 represent the HRI of the heavy metals by the consumption of food crops under study for both adults and children in Onne. The HRI of the heavy metals for adults and children was in the order: $\mathrm{Pb}>\mathrm{Cd}>\mathrm{Co}>\mathrm{Zn}>\mathrm{Mn}>\mathrm{Cu}>\mathrm{Ni}$ (M. paradisiaca); $\mathrm{Cd}>\mathrm{Pb}>\mathrm{Mn}>\mathrm{Co}>\mathrm{Cu}>\mathrm{Zn}>\mathrm{Ni}$ (Z. mays); $\mathrm{Cd}>\mathrm{Mn}>\mathrm{Co}>\mathrm{Pb}>\mathrm{Cu}>\mathrm{Zn}>\mathrm{Ni}$ (C. mannii); $\mathrm{Pb}>\mathrm{Cd}>\mathrm{Mn}>$ $\mathrm{Zn}>\mathrm{Cu}>\mathrm{Co}>\mathrm{Ni}$ (M. esculenta). The range of values of HRI of the heavy metals for adults and children were as follows: $0.7-$ 0.01 and 0.8-0.01 (M. paradisiaca); 0.6-0.016 and 0.7-0.019 (Z. mays); 0.6-0.005 and 0.7-0.005 (C. mannii); 0.95-0.015 and 1.075-0.18 (M. esculenta).

The estimated HRI of the heavy metals were all below one

Table 5. Health risk index of heavy metals for adults in Onne

\begin{tabular}{lccccccc}
\hline \multirow{2}{*}{ Leaf samples } & \multicolumn{5}{c}{ Health risk index } \\
\cline { 2 - 7 } & Lead $(\mathrm{Pb})$ & Cobalt (Co) & Cadmium (Cd) & Zinc (Zn) & Nickel (Ni) & Copper (Cu) & Manganese (Mn) \\
\hline Musa paradisiaca & 0.7 & 0.27 & 0.5 & 0.137 & 0.01 & 0.068 & 0.106 \\
Zea mays & 0.4 & 0.13 & 0.6 & 0.016 & ND & 0.038 & 0.306 \\
Cucumeropsis mannii & 0.3 & 0.47 & 0.6 & 0.006 & 0.005 & 0.058 & 0.533 \\
Manihot esculenta & 0.95 & 0.16 & 0.6 & 0.303 & 0.015 & 0.303 & 0.573 \\
\hline
\end{tabular}

ND: not detected.

Table 6. Health risk index of heavy metals for children in Onne

\begin{tabular}{lccccccc}
\hline \multirow{2}{*}{ Leaf samples } & \multicolumn{5}{c}{ Health risk index } \\
\cline { 2 - 7 } & Lead (Pb) & Cobalt (Co) & Cadmium (Cd) & Zinc (Zn) & Nickel (Ni) & Copper (Cu) & Manganese (Mn) \\
\hline Musa paradisiaca & 0.8 & 0.31 & 0.6 & 0.157 & 0.01 & 0.078 & 0.121 \\
Zea mays & 0.475 & 0.15 & 0.7 & 0.019 & ND & 0.043 & 0.352 \\
Cucumeropsis mannii & 0.325 & 0.54 & 0.7 & 0.006 & 0.005 & 0.068 & 0.612 \\
Manihot esculenta & 1.075 & 0.185 & 0.7 & 0.350 & 0.18 & 0.350 & 0.658 \\
\hline
\end{tabular}

ND: not detected. 
except $\mathrm{Pb}$ in M. esculenta, which had a HRI of 1.075 in children. HRI $<1$ indicates that the consumer population is safe from any potential health posed by the heavy metals, whereas HRI $>1$ implies that the consumer population is not safe [21, 22]. Since it was observed that HRI of Pb following the consumption of cassava by children was 1.075 , it implies that $\mathrm{Pb}$ could cause severe health risk to children consuming cassava products in Onne. $\mathrm{Pb}$ is particularly dangerous to children because their brain tissues and nervous systems are more sensitive to the damaging effects of $\mathrm{Pb}$. Low levels of $\mathrm{Pb}$ in the blood of children results in behavioral and learning problems, lower intelligence quotient (IQ) and hyperactivity, slowed growth, hearing problems and anemia [46].

It has been reported that the food chain (soil-plant-man) is the most common and important exposure pathway of heavy metals such as $\mathrm{Pb}, \mathrm{Cd}$, and $\mathrm{Ni}$, to human [47]. Thus, reduction in the concentration of pollutants such as $\mathrm{Pb}$ in the soil would reduce its health risks to humans. Possible remediation techniques for $\mathrm{Pb}$ in soil include chemical immobilization/stabilization methods by adding some non-toxic materials into the soil to reduce the solubility of the heavy metal, mixing the polluted soils with clean unpolluted soils in order to reduce the heavy metal concentration in the soil. Other contemporary remediation methods are electromigration process, washing/ leaching/flushing the soil with chemical agents such as cyclodextrins, surfactants, chelating agents and organic acids either ex situ or in situ [8, 48-50].

\section{Conclusion}

The health risk posed by heavy metals to humans and animals can be circumvented by analyzing the level of metal contamination in farmlands. The present study noted a high bioaccumulation of toxic heavy metals from soil sample in $M$. esculenta cultivated in Onne. The HRI of $\mathrm{Pb}$ in cassava was reported to be greater than 1 , indicating that the consumption of such food will pose a significant health risk to the populace, especially children. It is therefore recommended that the local populace, especially children, of Onne should abstain from cassava-based meals in order to reduce $\mathrm{Pb}$ bioaccumulation and concomitant health risks. However, the concentrations of $\mathrm{Co}, \mathrm{Cd}, \mathrm{Zn}, \mathrm{Ni}, \mathrm{Cu}$ and $\mathrm{Mn}$ in plantain-, maize- and melonbased meals were relatively within safe limits.

\section{Conflict of interest}

The authors declare no conflict of interest with respect to the publication of this manuscript.

\section{CRediT Author Statement}

FOO: Investigation, Writing-Original Draft Preparation, Resources. KCL: Supervision, Conceptualization. PCC: WritingReviewing and Editing, Visualization. AWV: Methodology, Resources. CEE: Data Curator, Resources.

\section{Acknowledgment}

The authors are grateful for the technical assistance offered by Mr. O.A.K. Emenyonu, Chief Academic Technologist, Department of Biochemistry, Imo State University, Owerri.

\section{References}

1. Imam MZ, Akter S. Musa paradisiaca L. and Musa sapientum L.: A phytochemical and pharmacological review J Appl Pharm Sci 2011; 1(5):14-20.

2. Lakshmi V, Agarwal SK, Mahdi AA, Bhattacharya SM, Guiama VD, Ngah E et al. An overview of Musa paradisiaca Linn. NPAIJ 2015;11(4): 105-109.

3. Milind P, Isha D. Zea maize: A modern craze. Int Res J Pharm 2013; 4(6):39-43.

4. Essien EA, Umoren SA, Essien EE, Udoh AP. Preparation and evaluation of Cucumeropsis mannii (Naud.) seed oil metallic soaps as driers in Gloss paint. J Mater Environ Sci 2012;3(3):477-484.

5. Bahekar S, Kale R. Phytopharmocological aspects of Manihot esculenta Crantz (cassava) - A review. Mintage J Pharm Med Sci, 2013;2:4-5.

6. Ha CD, Quynh LTN, Hien NT, Thu PTL, Ham LH, Dung LT. Morphological characterization and classification of cassava (Manihot esculenta Crantz) in Vietnam. Tap Chi Sinh Hoc 2016;38(3):344-351.

7. Fomekong A, Messi J, Kekeunou S, Tchuenguem-Fohouo F, Tamesse JL. Entomofauna of Cucumeropsis mannii Naudin, its impact on plant yield and some aspects of the biology of Dacus bivitattus (Diptera: Tephritidae). Afr J Agric Res 2008;3(5):363-370.

8. Wuana RA, Okleimen FE, Imborvungu JA. Removal of heavy metals from a contaminated soil using organic chelating acids. Int J Environ Sci Tech 2010;7(3):485-496.

9. Akoto O, Ephraim JH, Darko G. Heavy metals pollution in surface soils in the vicinity of abundant railway servicing workshop in Kumasi, Ghana. Int J Environ Res 2008;2(4):359-364.

10. Emmanuel A, Cobbina SJ, Adomako D, Duwiejuah AB, Asare W. Assessment of heavy metals concentration in soils around oil filling and service stations in the Temale Metropolis, Ghana. Afr J Environ Sci Technol 2014;8(4):256-266.

11. Allen F. Dangerous air pollution in the city of Port Harcourt. Pambazuka News 2017; [cited 2012 Feb 6]. Available from: https://www. pambazuka.org/node/96487

12. Oladeji JT, Adetola SO, Ogunsola AD. Heavy metal concentrations in soil of Ogbomoso and its environs. Merit Res J Environ Sci Toxicol 2016;4(1):1-5.

13. Asia IO, Jegede SI, Jegede DA, Ize-Iyamu OK, Akpasubi EB. The effects of petroleum exploration and production operations on the heavy metals contents of soil and groundwater in the Niger Delta. Int J Phys Sci 2007;2(10):271-275. 
14. Moremi OO, Horsfall Jnr M, Okorosaye-Orubite K. Total levels of some heavy metals in cassava tuber from Eleme Local Government Area of Rivers State, Nigeria. Res J Chem Sci 2016;6(5):1-5.

15. Kigigha LT, Nyenke P, Izah SC. Health risk assessment of selected heavy metals in garri (cassava flake) sold in some major markets in Yenagoa metropolis, Nigeria. MOJ Toxicol 2018;4(2):47-52.

16. Ibe FC, Beniah OI, Enyoh CE. Trace metals analysis of soil and edible plant leaves from abandoned municipal waste dumpsite in Owerri, Imo State, Nigeria. World News Nat Sci 2017;13:27-42.

17. Enyoh CE, Ihionu EA, Verla AW, Ebosie PN. Physicochemical parameter of palm oil and soil from Ihube Community, Okigwe, Imo State, Nigeria. Int Lett Nat Sci 2017;62:35-43.

18. Enemugwem RI, Baridagara SC, Mikue-Yobe TF, Ekejiuba C, Nwileba A, Elechi P. Effect of heavy metals on cassava tubers (Manihot esculenta) and pumpkin leaves (Telfairia occidentalis) from prison farm in Elele, Ikwerre LGA of Rivers State, Nigeria. Int J Sci Eng Res 2016;7 (12):1454-1463.

19. Isiuku BO, Enyoh CE. Monitoring and modeling of heavy metal contents in vegetables collected from markets in Imo State, Nigeria. Environ Anal Health Toxicol 2020;35(1):15-27.

20. Lago-Villa M, Arenas-Lago D, Rodriguez-Seijo A, Andrade-Counce ML, Vega FA. Cobalt, chromium and nickel contents in soils and plants from a serpentine quarry. Solid Earth 2015;6(1):323-335.

21. Okereke CJ, Essien EB, Wegwu MO. Human Health Risk assessment of heavy metal contamination for population via consumption of selected vegetables and tubers grown in farmlands in Rivers State, South-South Nigeria. J Anal Pharm Res 2016;3(6):00077.

22. Osu SR, Solomon MM, Abai EJ, Etim IG. Human health risk assessment of heavy metals intake via cassava consumption from crude oil impacted soils with and without palm bunch ash additive. Int J Tech Res Appl 2015;3(4):140-148.

23. Gebreyohannes F, Gebrekidan A. Health Risk Assessment of heavy metals via consumption of spinach vegetable grown in Elalla River. Bull Chem Soc Ethiopia 2018;32(1):65-75.

24. Ogundele DT, Adio AA, Oludele OE. Heavy metal concentrations in plants and soil along heavy traffic roads in North Central Nigeria. J Environ Anal Toxicol 2015;5(334):2161-0525.

25. Dabanović V, Soskic M, Durovic D, Mugosa B. Investigation of heavy metals content in selected tea brands marketed in Podgorica, Montenegro. Int J Pharm Sci Res 2016;7(12):4798-4704.

26. World Health Organization (WHO). Permissible limits of heavy metals in soil and plants. Geneva, Switzerland;1996.

27. Simonsen LO, Harbak H, Bennekou P. Cobalt metabolism and toxicology- A brief update. Sci Total Environ 2012;432:210-215.

28. Tegegne WA. Assessment of some heavy metals concentration in selected cereals collected from local markets of Ambo City, Ethiopia. J Cereals Oilseeds 2015;6(2):8-13.

29. Edward JB, Idowu EO, Oso JA, Ibidapo OR. Determination of heavy metal concentration in fish samples, sediment and water from OdoAyo River in Ado-Ekiti, Ekiti State, Nigeria. Int J Environ Monit Anal 2013;1(1):27-33.

30. Plum LM, Rink L, Haase H. The essential toxin: Impact of zinc on human health. Int J Environ Res Public Health 2010;7(4):1342-1365.

31. Ajiwe VIE, Chukwujindu KC, Chukwujindu CN. Heavy metals concentration in cassava tubers and leaves from Galena mining area in Ishiagu, Ivo L.G.A. of Ebonyi State, Nigeria. ISOR J Appl Chem 2018;
11(3):54-58.

32. Kalagbor IA, Dighi NK, James R. Levels of some heavy metals in cassava and plantain from farmlands in Kaani and Kpean in Khana Local Government Area of Rivers State. J Appl Sci Environ Manag 2015;19 (2):219-222.

33. Ajayi I, Salami A. Evaluation of Cucumeropsis mannii seed cake. Nat Sci2013;11(7):86-93.

34. Akenga T, Sudoi V, Machuka W, Kerich E, Ronoh E. Heavy metals uptake in maize grains and leaves in different agro ecological zones in Uasin Gishu County. J Environ Prot 2017;8(12):1435-1444.

35. Opaluwa OD, Aremu MO, Ogbo LO, Abiola KA, Odiba IE, Abubakar MM, et al. Heavy metal concentrations in soils, plant leaves and crops grown around dumpsites in Lafia Metropolis, Nasarawa State, Nigeria. Adv Appl Sci Res 2012;3(2):780-784.

36. Fosu-Mensah BY, Addae E, Yirenya-Tawiah D, Nyame F. Heavy metals concentration and distribution in soils and vegetation at Korle Lagoon Area in Accra, Ghana. Cogent Environ Sci 2017;3(1):1405887.

37. Auta T, Morenikeji OA. Heavy metal concentrations around a hospital incinerator and municipal dumpsite in Ibadan City, South-West Nigeria. J Appl Sci Environ Manag 2013;17(3):419-422.

38. Ofudje EA, Alayande SO, Oladipo GO, Williams OD, Akiode OK. Heavy metals concentration at electronic waste dismantling sites and dumpsites in Lagos, Nigeria. Int Res J Pure Appl Chem 2014;4(6):678690.

39. Ekmekyapar F, Sabudak T, Seren G. Assessment of heavy metal contamination in soil and wheat (Triticum aestivum $\mathrm{L}$.) plant around the Corlu-Cerkezkoy highway in Thrace Region. Global NEST J 2012;14 (4):496-504.

40. Yan X, Zhang F, Zeng C, Zhang M, Devkota LP, Yao T. Relationship between heavy metal concentrations in soils and grasses of roadside farmland in Nepal. Int J Environ Res Public Health 2012;9(9):32093226.

41. Zhuang P, McBride MB, Xia H, Li N, Li Z. Health risk from heavy metals via consumption of food crops in the vicinity of Dabaoshan mine, South China. Sci Total Environ 2009;407(5):1551-1561.

42. Harrison UE, Osu SR, Ekanem JO. Heavy metals accumulation in leaves and tubers of cassava (Manihot esculenta Crantz) grown in crude oil contaminated soil at Ikot Ada Udo, Nigeria. J Appl Sci Environ Manag 2018;22(6):845-851.

43. Cui YJ, Zhu YG, Zhai RH, Chen DY, Huang YZ, Qui Y, et al. Transfer of metals from soil to vegetables in an area near a smelter in Nanning, China. Environ Inter 2004;30(6):785-791.

44. Joint FAO/WHO expert committee on food additives (JEFCA). Joint FAO/WHO expert committee on food additives toxicological evaluation of certain food additives. International Life Sciences Institute (ILSI press): Washington, USA;1999.

45. Khan MA, Mehmood S, Ullah F, Khattak A, Zeb MA. Health risks assessment diagnosis of toxic chemicals (heavy metals) via food crops consumption irrigated with wastewater. Sains Malays 2017;46(6):917924.

46. US-EPA: United States, environmental protection agency. [cited 2017 Feb 6]. Available from: http://www.epa.gov/lead/learn-about-lead

47. Khan S, Cao Q, Zheng YM, Huang YZ, Zhu YG. Health risks of heavy metals in contaminated soils and food crops irrigated with waste water in Beijing, China. Environ Pollut 2008;152(3):686-692.

48. Fawzy EM. Soil remediation using in-situ immobilization techniques. 
Franklyn 0. Ohiagu, et al. I Bioaccumulation and health risk assessment of heavy metals

Chem Ecol 2008;24(2):147-156.

49. Nouri J, Khorasani N, Lorestani B, Karami M, Hassani AH, Yousefi N Accumulation of heavy metals in soil and uptake by plant species with phytoremediation potential. Environ Earth Sci 2009;59(2):315-
323.

50. Kord B, Mataji A, Babaie S. Pine (Pinus eldarica Medw.) needles as indicator for heavy metals pollution. Int J Environ Sci Tech 2010;7(1): 79-84. 